\title{
Demographic Transition and Home Care for the Elderly in Bangladesh: An Urban Rural Comparison
}

\author{
Mohammad Abdul Hannan Pradhan*, Sadika Akthar, Md. Gias Uddin Khan, Mohammad Rafiqul Islam
}

Department of Economics, Shahjalal University of Science and Technology, Bangladesh

Copyright $(2017$ by authors, all rights reserved. Authors agree that this article remains permanently open access under the terms of the Creative Commons Attribution License 4.0 International License

\begin{abstract}
During the last few decades, the proportion of elderly people has increased rapidly in Bangladesh. With the increase of elderly people, it is required to increase in the provision of care for them, either informal or formal. Family was the prime informal care giver. However, the traditional concept of family and sources of home care systems have been changed. Besides, the formal care system is very limited and located in the urban areas. The study was an attempt to determine and analyze the vulnerability of the elderly to the home care received in both areas. The respondents aged 60 years and above were interviewed with structured questionnaire. Considering some common characteristics like age, number of children, previous job status, children's job status, living arrangement and others, marginal effect to receive care like financial, practical or personal is estimated using Probit model to address the more influencing factor to be vulnerable. The findings reveal that the elderly are more vulnerable in receiving personal care than practical and financial care in rural areas. The elderly in rural area are financially more vulnerable than urban area. In addition, the elderly in rural area are less vulnerable in receiving care from relatives, friends and neighbors than urban area. Findings suggest that policymakers urgently need to take into consideration to provide home care for the elderly.
\end{abstract}

Keywords Elderly, Demographic Transition, Home Care, Marginal Effect, Vulnerability

\section{Introduction}

Bangladesh, as a developing country, is experiencing the growing number of older populations [1, 2, 3]. The latest population census found that about 7 percent of the total population is 60 years old and above. It is projected that the country's aged population will be reached at 20 percent of the total population-more than three-fold increase from the present time by 2050[4].In addition, the increase in elderly population during the period $1990-2025$ is projected to be much faster than that of some European countries such as Sweden (33\%), UK (45\%) or Germany (66\%). Thus, these changes might affect the overall socio-economic development of the country. Elderly people, in most cases, are unable to accomplish their daily activities. They necessitate help to do indispensable tasks like home care. With the increase of elderly people, it is also required to increase in the provision in the home care, either informal or formal. In order to meet the increasing demand for home care, the supply of different informal or formal care is required to increase to tackle the situation.

Traditionally, informal care provision means that the care from adult children including spouse. During the last few decades, the rapid urbanization, modernization, industrialization and globalization have changed the traditional concept of family and traditional sources of home care systems for the elderly [5, 6, 7, 8]. On the other hand, formal care system is very limited both in the urban and rural areas considering the level of requirement due to financial limitation and less intention to set up the system as required.

The elderly in Bangladesh normally reach aged 60 years and over following a life time of poverty and deprivation, poor access to health care and poor diet. They do not have pension coverage due to their life involving in subsistence agriculture and informal labor market. Besides, the formal social security systems are very limited coverage along with inadequate benefits payments [9]. As a result, majority of the elderly are depended on their family members for home care [10]. In addition, urbanization and industrialization have led to the changes in economic structure, diminishing the social values and weakening the importance of joint family $[11,12]$. Thus, the elderly are captivated between the decline in traditional values and absence to adequate social safety net [13].

Nowadays, it is hypothesized that the changing lifestyles along with urbanization and the declining of the traditional family system and support might increase the difficulty of the elderly people, especially in the rural areas. Poverty is one of the important reasons for weakening the traditional 
form of family support for the elderly [14]. As a result, role of relatives, friends and neighbors for the elderly care might increase notably, at the same time might be sustainable both in urban and rural areas. A little attention has been paid by the policy makers to address these issues realizing their needs. In the absence of a comprehensive and realistic national policy on the elderly, the individual small-scale programs by the various development actors remain largely untapped without direction and coordinated action.

Traditionally parents, their children, their children's spouse, and grandchildren all live together. The man worked outside for earning and the women of the family care the children, home and others. Family was the main foundation for taking care of elderly. Hence, the elderly might face the less problem. As extended family system has been replaced by nuclear family, it can be commonly hypothesized that home care for the elderly declines and the elderly become more vulnerable to have care. Main objective of the study is to determine and analyze the vulnerability of the elderly to the home care received and to compare the probability of receiving care in rural and urban area. As the home care issue was not included in the national survey, data were collected using a structured questionnaire interviewing the respondents aged 60 years and above living in urban and rural area of Sylhet district. Existing research is limited in the area of role and status of elderly, identify the causes and consequences of the aging [15] with their needs, their projected distribution [1], care services and existing situation [7], their needs and health condition [16], socio-economic status even quality of elderly life [17].

But aging brings a distinctive set of problems. People move from "middle age to young old age" and then to old age and death. In this transition, five crises are almost universal: loss of social status; loss of significant; internal and external body changes reflecting biological decline; confrontation with death; and modification of available roles and activities $[18,19]$. Thus,the elderly need different kind of care. Moreover, they might suffer from loneliness. Practically, they need proper care at the end stage of their life. This study was an attempt to address different kinds of care received by the elderly, specifically analyze the current homecare provider for elderly and role of relatives, friend and neighbor in rural and urban areas. Finally, the study determines and analyzes the vulnerability of the elderly to the home care received in both areas collecting data from the respondents with structured questionnaire survey. As existing researches hardly address this issue, findings facilitate the government and policy makers to formulate framework to provide required care for the elderly.

\section{Home Care, Views and Related Literature}

The elderly is associated with the age at which one can begin to receive pension benefits. The UN agreed cutoff age is $60+$ years to refer to the older population. In Bangladesh, the elderly are defined as persons in age group of 60 and over. The age limit is partly decided by current norms about the retirement applicable in formal or informal organization. However, the elderly require home care because of the declining of their physical strength. Generally, home care means supportive care provided in the home. Home care is defined as financial, personal and practical care received from spouse, children, relatives, friend and neighbor, government, NGO, and paid home servant [20]. Informal care means the unpaid care provided by family, friends or neighbors [21]. Informal home care is defined as unpaid home care by spouse, children, relatives, friend and neighbor, includes three tasks: (1) Personal care, such as dressing, bathing or showering, eating, getting in or out of bed, using the toilet; (2) Help with practical household tasks, such as preparing meals, taking medication, housework, going out, for example to doctor's appointments or shopping, making phone calls or writing letters. And (3) help with paperwork, such as filling out forms and settling financial or legal matters. Besides, formal home care is defined as professional or paid home care includes three tasks: (1) nursing or personal care, (2) home help, and (3) meals-on-wheels [20].

Traditionally, it is a common believe in every society that every human should do care for their parents. Parents give countless favors to their children and provide protection, food and clothing to the newly born child whereas mother sacrifices her comforts and sleeps to provide comfort to her children [22]. Similarly the father works hard to provide for their physical, educational and psychological needs. It is would be a common practice to repay and compensate him for his gifts and favors [23].

Every religion provides importance on homecare for parents. Islam and Hinduism strongly emphasized on the duty of children to love, respect, and support their parents; Judaism and Christianity are clear about the moral importance of filial duty, rooted in teachings at the heart of their common theological-ethical heritage. However, Buddhism is unique in that its teachings emphasized on the eternal and fathomless kindness of a mother and solemn filial obligation to repay the kindness in her old age [23].

Considering legal point of view, the government of Bangladesh has passed act by its parliament named "The Parent's Care Act, 2013”. It is a law to make sure social protection of the elderly and obliged the children to take care of their parents. By the law, the children will be bound to take care of their parents and provide them with food and shelter. According to the act, every child will have to spend ten percent of their total income and to meet their parents if they stay far away. Even children are not allowed to send their parents in old age homes without their wishes. The law also allows parents to file cases against their children if they beg to be excused to support them.

Previous studies have mainly attempted to emphasize on the causes and consequences of ageing in Bangladesh [24, 14 , and 25]. Where very few study focus on home care of 
the elderly. Aging issue has become a main concern recently because the demographic transition started changing. In the next decades, the country will experience rapid growth of elderly population.

\section{Research Location, Survey Technique and Data Analysis}

The study was carried out in Sylhet district of Bangladesh conducting survey in 2015 to collected data from the respondents aged 60 and above. Data were collected from 366 respondents dividing according to the urban-rural ratio as the World Bank measured in 2012. About 29 and 71 percent of the sample were taken from urban and rural area, respectively. All samples from urban area are taken from Sylhet Metropolitan area. Simultaneously about 35.2 and 35.8percent of the sample were taken from Kanaighat and from Balaginjupzilla, respectively in Sylhet district which is treated as rural area. Respondents were identified by collecting voter list considering authentic source of information about the all citizen and surveyed if he/she was found in the house on the survey date. A structured questionnaire survey technique was administered to collect data as it is the most widely used survey instrument [26]. The questionnaire was formulated for socio-economic characteristics based on Household Income Expenditure Survey (HIES)-2010 used by the Bangladesh Bureau of Statistics (BBS). Besides, homecare related instrument in the questionnaire was taken from literature [20]. Then pilot survey was conducted to check whether the respondents understand and respond correctly. Same technique also is used to assess the care receive of Older Dutch people [27]. Using this technique, quantitative information of the socio-economic charactersand children characteristics of the respondents was collected. Besides, informal and formal care received, future expectation on home care received and other aspects of the respondents were collected. Generally, the respondents received two categories of home cares like informal and formal. Informal care provider includes spouse, children, relatives, friends and neighbors. Formal home care provider includes government, NGO and paid home servant. Informal care includes financial care, personal care and practical care. Personal care is the care of dressing, bathing, eating, getting in or out of bed and using the toilet. Practical care contains the care of preparing meals, taking medication, housework, going out, for example to doctor's appointments or shopping, making phone calls or writing letters [20].
Descriptive statistics were used to characterize the sample based on socio-economic data, informal and formal care provider, and expectation on future home care. To measure the vulnerability of home care received, the study used binary Probit regression model separately for the respondents from urban and rural area. Respondents' socioeconomic characters and children characteristics were used as explanatory variable. Gender (gen) age, marital status (ms), education (edu), previous job status (pjs), source of income (soi), living arrangement (lia), number of siblings (sib), sociability (soi) were considered as respondents' socioeconomic characters. Besides, the respondent has son (hs), number of son (nos), has daughter (hd), number of daughter (nod), children age (ca), marital status of children (mc), children's employment status (ec) and whether children live (cl) were used as children characteristics. All variable were categorical (dummy) except respondent's age, number of son, number of daughter, and number of sibling. Then vulnerability was estimated considering whether the respondents receive financial care from children, relatives, and friends and neighbors, respectively. Similarly, whether the respondents receive personal and practical cares from children, relatives, and friends and neighbors, respectively.

\section{Survey Findings and Discussion}

\subsection{Descriptive Statistics}

Table 1 depicts the distributions of the demographic and the social-economic characteristics of the respondents separately for urban and rural area. More than $70 \%$ respondents were from rural as the most of the people live in rural area. Besides, female respondents were higher than male both in urban and rural areas. The numbers of urban elderly were higher in age group 60-69 and 80+ than rural. The rate of widow among the respondents in rural areas $(42.3 \%)$ is higher than urban area (30.2\%). Considering the literacy rate, the majority of elderly were found literate in the urban area. This scenario is reverse in rural area. Many evidences suggest that psychological and sociological factors have a significant influence on how well the elderly are. The study found that about $47 \%$ of the respondents were engaged in different social activity, specifically in religious group. This kind of sociability of elderly plays an important role in protecting them from the experiencing of psychological distress and in enhancing well-beings. 
Table 1. Socio-economic Characteristics of the respondents

\begin{tabular}{|c|c|c|c|c|}
\hline Characteristics & Urban & Rural & Total & $\%$ \\
\hline $\begin{array}{l}\text { Gender } \\
\text { Male } \\
\text { Female } \\
\text { Total }\end{array}$ & $\begin{array}{c}47(12.8 \%) \\
59(16.2 \%) \\
106(29 \%)\end{array}$ & $\begin{array}{c}104(28.4 \%) \\
156(42.6 \%) \\
260(71 \%)\end{array}$ & $\begin{array}{l}151 \\
215 \\
366 \\
\end{array}$ & $\begin{array}{r}41.3 \\
58.7 \\
100 \\
\end{array}$ \\
\hline $\begin{array}{c}\text { Age } \\
60-69 \\
70-79 \\
80+\end{array}$ & $\begin{array}{c}67(63.2 \%) \\
21(19.8 \%) \\
18(17 \%)\end{array}$ & $\begin{array}{c}133(51.1 \%) \\
85(32.7 \%) \\
42(16.2 \%)\end{array}$ & $\begin{array}{c}200 \\
106 \\
60 \\
\end{array}$ & $\begin{array}{c}54.6 \\
29 \\
16.4\end{array}$ \\
\hline $\begin{array}{l}\text { Marital Status } \\
\text { Married } \\
\text { Divorce } \\
\text { Widow } \\
\end{array}$ & $\begin{array}{c}73(68.9 \%) \\
1(0.9 \%) \\
32(30.2 \%)\end{array}$ & $\begin{array}{c}146(56.2 \%) \\
4(1.5 \%) \\
110(42.3 \%)\end{array}$ & $\begin{array}{c}219 \\
5 \\
142 \\
\end{array}$ & $\begin{array}{c}59.8 \\
1.4 \\
38.8 \\
\end{array}$ \\
\hline $\begin{array}{c}\text { Education } \\
\text { Illiterate } \\
\text { Literate (only sing) } \\
\text { Primary Education } \\
\text { JSC/Equivalent } \\
\text { SCC/Equivalent } \\
\text { HSC/Equivalent } \\
\text { Graduate/Equivalent }\end{array}$ & $\begin{array}{c}21(19.8 \%) \\
21(19.8 \%) \\
25(23.6 \%) \\
12(11.3 \%) \\
10(9.4 \%) \\
6(5.6 \%) \\
11 .(10.4 \%)\end{array}$ & $\begin{array}{c}159(61.2 \%) \\
44(16.9 \%) \\
40(15.4 \%) \\
6(2.3 \%) \\
7(2.7 \%) \\
1(0.4 \%) \\
3(1.2 \%)\end{array}$ & $\begin{array}{c}180 \\
65 \\
65 \\
18 \\
17 \\
7 \\
14\end{array}$ & $\begin{array}{c}49.2 \\
17.8 \\
17.8 \\
4.9 \\
4.6 \\
1.9 \\
3.8\end{array}$ \\
\hline $\begin{array}{l}\text { Current Income Source } \\
\text { Self-dependent } \\
\text { Son’s income } \\
\text { Daughter's income } \\
\text { Siblings income } \\
\text { Relatives income } \\
\text { Spouse income }\end{array}$ & $\begin{array}{c}23(21.7 \%) \\
63(59.4 \%) \\
6(5.7 \%) \\
5(4.7 \%) \\
7(6.6 \%) \\
2(1.9 \%)\end{array}$ & $\begin{array}{c}44(16.9 \%) \\
184(70.8 \%) \\
4(1.5 \%) \\
10(3.8 \%) \\
13(5 \%) \\
5(1.5 \%)\end{array}$ & $\begin{array}{c}67 \\
247 \\
10 \\
15 \\
20 \\
7\end{array}$ & $\begin{array}{c}18.3 \\
67.5 \\
2.7 \\
4.5 \\
5.5 \\
1.9\end{array}$ \\
\hline $\begin{array}{l}\text { Living Arrangement } \\
\text { Live alone } \\
\text { Lives with children } \\
\text { Lives with relatives } \\
\text { Lives with others }\end{array}$ & $\begin{array}{c}7(6.6 \%) \\
92(86.8 \%) \\
5(4.7 \%) \\
2(1.9 \%)\end{array}$ & $\begin{array}{c}17(6.5 \%) \\
200(76.9 \%) \\
36(13.8 \%) \\
7(2.7 \%)\end{array}$ & $\begin{array}{c}24 \\
292 \\
41 \\
9\end{array}$ & $\begin{array}{c}6.6 \\
79.8 \\
11.2 \\
2.5\end{array}$ \\
\hline $\begin{array}{c}\text { Sociability } \\
\text { Religious group } \\
\text { Charity club } \\
\text { Social club } \\
\text { Political party } \\
\text { None }\end{array}$ & $\begin{array}{c}34(32.1 \%) \\
0(0 \%) \\
1(0.95 \%) \\
2(1.9 \%) \\
69(65.05 \%)\end{array}$ & $\begin{array}{c}129(49.6 \%) \\
0 \\
1(0.4 \%) \\
4(1.5 \%) \\
125(48.5 \%)\end{array}$ & $\begin{array}{c}163 \\
0 \\
2 \\
6 \\
194\end{array}$ & $\begin{array}{c}44.5 \\
0 \\
.5 \\
1.8 \\
53.2\end{array}$ \\
\hline
\end{tabular}

Source: Author's estimation from Survey data

\subsection{Probability of Receiving Home Care}

Table2 reports the estimated results for financial care received by the respondents in urban and rural area separately provided by spouse and children. In the rural area, education, source of income, number of sons and children's employment status are significant predictors of financial care received from spouse and children. On the other hand, age, gender, education and source of income are significant predictors for the urban respondents. In the rural area, the marginal effect of education, source of income and children's employment status are 11.6, 23.7 and 13.1 percent, respectively. This result indicates that education plays an important role in receiving care from spouse and children because educated person might have educated spouse. Besides, they might have educated children who are good income earner or more responsible to their parents. Thus, in the rural area probability of receiving financial care from spouse and children is more for literate respondents than illiterate.

Source of income is another significant predictor because when the elderly depend on other income it indicates they are unable to fulfill their needs. As the most of the respondents were not self-dependent, there is a high probability of receiving care from others, specifically from children. In addition, when more children are involved in formal job sectors, probability of receiving financial care from children increases. For the urban area, each additional year of age, elderly is 0.9 percent less likely to get financial care from spouse and children because with increasing elderly age their children age also increase. Thus they may concentrate on their own family affairs. However, the probability of receiving financial care is more for woman than man. The study found similar results for the respondents in urban area (Table 2). In receiving personal care for the rural respondents, marital status and married children are significant predictors as shown in Table 3. For disable elderly, spouse is the most important personal care provider. On the other hand, if child is married, probability of receiving care falls by 3 percent. As children specifically daughters provide personal care to their parents, they go them away after marriage. However in case of urban area, there is no significant predictor. 
Table 2. Estimated Results for the Elderly Received Financial Care from Spouse and Children

\begin{tabular}{|c|c|c|c|c|}
\hline \multirow{3}{*}{$\begin{array}{l}\text { Dependent Variables } \\
\text { Independent Variables }\end{array}$} & \multicolumn{2}{|c|}{ Financial Care (Rural Area) } & \multicolumn{2}{|c|}{ Financial Care (Urban Area } \\
\hline & \multicolumn{2}{|c|}{ Marginal Effect } & \multicolumn{2}{|c|}{ Marginal Effect } \\
\hline & Estimate & z-Value & Estimate & z-Value \\
\hline Age & -0.0018 & -0.54 & $-0.009 * *$ & -1.95 \\
\hline Gender & -0.0110 & -0.18 & $-0.182 *$ & -1.84 \\
\hline Marital Status & 0.062 & 1.03 & -0.034 & -0.48 \\
\hline Education & $0.116^{* *}$ & 2.11 & $0.084^{*}$ & 1.94 \\
\hline Source of income & $0.237 * *$ & 2.62 & $0.596 * * *$ & 3.76 \\
\hline Living Arrangement & 0.064 & 1.00 & 0.064 & 0.46 \\
\hline Sociability & -0.0029 & -0.07 & 0.0014 & 0.02 \\
\hline Number of siblings & -0.008 & -0.95 & 0.011 & 0.99 \\
\hline Number of sons & $0.097 * * *$ & 4.64 & 0.029 & 1.02 \\
\hline Number of daughters & 0.013 & 0.85 & -0.006 & -0.27 \\
\hline Children Age (Average) & 0.0023 & 0.81 & 0.002 & 0.52 \\
\hline Married Children (average) & 0.166 & 1.66 & 0.098 & 1.23 \\
\hline Children’s employment (average) & $0.131^{* *}$ & 3.37 & 0.075 & 1.00 \\
\hline Livings (Average) & 0.038 & 0.79 & -0.027 & -0.33 \\
\hline Probit Regression & \multicolumn{2}{|c|}{$\begin{array}{c}\text { Number of obs. }=260 \\
\text { LR chi2 }(14)=114.42 \\
\text { Prob. } \geq \text { chi2 }=0.0000 \\
\text { Pseudo } R^{2}=0.43 \\
\text { Irritation }=5 \\
\text { Log likelihood }=-75.618\end{array}$} & \multicolumn{2}{|c|}{$\begin{array}{c}\text { Number of obs. }=106 \\
\text { LR chi2 }(14)=43.11 \\
\text { Prob. } \geq \text { chi2 }=0.0001 \\
\text { Pseudo } R^{2}=0.45 \\
\text { Irritation }=5 \\
\text { Log likelihood }=-26.74\end{array}$} \\
\hline
\end{tabular}

Note: Coefficient significant at least 10 percent level is shown in bold type; and level of significance: ${ }^{* * *} \mathrm{p}<0.01 ;{ }^{* *} \mathrm{p}<0.05 ;{ }^{*} \mathrm{p}<0.10$.

Table 3. Estimation Result for the Elderly Received Personal Care from Spouse and Children

\begin{tabular}{|c|c|c|c|c|}
\hline \multirow{3}{*}{$\begin{array}{l}\text { Dependent Variables } \\
\text { Independent Variables }\end{array}$} & \multirow{2}{*}{\multicolumn{2}{|c|}{ Personal Care (Rural Area) }} & \multirow{2}{*}{\multicolumn{2}{|c|}{$\begin{array}{c}\text { Personal Care (Urban Area } \\
\text { Marginal Effect }\end{array}$}} \\
\hline & & & & \\
\hline & Estimate & z-Value & Estimate & z-Value \\
\hline Age & -0.003 & -1.53 & 0.0009 & 0.71 \\
\hline Gender & -0.148 & -2.50 & -0.027 & -0.82 \\
\hline Marital Status & $0.002 * * *$ & 0.01 & -0.014 & -0.47 \\
\hline Education & 0.025 & 0.97 & -0.014 & -0.71 \\
\hline Sociability & -0.038 & -1.42 & -0.013 & -0.74 \\
\hline Number of siblings & 0.0013 & 0.27 & -0.001 & -0.49 \\
\hline Number of sons & 0.013 & 1.29 & -0.002 & -0.30 \\
\hline Number of daughters & -0.003 & -0.30 & 0.009 & 0.82 \\
\hline Children Age (Average) & 0.003 & 1.47 & -0.00006 & -0.07 \\
\hline Married Children (average) & $-0.003^{*}$ & -0.07 & 0.006 & 0.47 \\
\hline Children’s employment (average) & -0.008 & -0.32 & -0.005 & -0.24 \\
\hline Livings (Average) & -0.078 & -2.59 & -0.001 & -0.09 \\
\hline Probit Regression & $\begin{array}{l}\mathrm{Nu} \\
\mathrm{LR} \\
\mathrm{Pr} \\
\mathrm{Ps} \\
\mathrm{Log}\end{array}$ & & & \\
\hline
\end{tabular}

Note: Coefficient significant at least 10 percent level is shown in bold type; and level of significance: ${ }^{* * *} \mathrm{p}<0.01 ;{ }^{* *} \mathrm{p}<0.05 ;{ }^{*} \mathrm{p}<0.10$ 
Considering the practical care, source of income, livings arrangement and children livings are significant predictors for the rural area (Table 4). Respondents are more likely to receive practical care from spouse and children if they live with children or spouse. Elderly live with children is 21 percent more likely to receive practical care from their spouse and children because it is easy for them to take care of their parents. On the other hand, in case of urban area livings arrangement is only significant predictor in receiving practical care from spouse and children. Elderly live with children is 34.4 percent more likely to receive practical care from their spouse and children.

For the rural respondents, age of the respondent, children average age, marital status of children and employed status of children are significant predictors for receiving financial care from relatives (Table 5). Age, married children and employment children are less likely to receive financial care by elderly from relatives and only average children age is more likely to receive this care. For each additional year of age, elderly are 1.6 percent less likely to get financialcare from relatives. Marginal effect of elderly employment status and marital status are 41.3 and 22.6 percent, respectively. In case of urban area only children employment status is significant predictor, which is less likely to receive financial care from relatives.

Elderly age and children livings status are significant predictors for receiving personal care from relatives for the rural respondents (Table 6). In Bangladesh daughter-in-law is an important care provider. With increasing age, most of them lose their spouse and daughters go them away after marriage. Thus probability of receiving personal care from relatives will increase with increasing age.

Table 4. Estimation Result for the Elderly Received Practical Care from Spouse and Children

\begin{tabular}{|c|c|c|c|c|}
\hline \multirow{3}{*}{$\begin{array}{l}\text { Dependent Variables } \\
\text { Independent Variables }\end{array}$} & \multicolumn{2}{|c|}{ Practical Care (Rural Area) } & \multicolumn{2}{|c|}{ Practical Care (Urban Area } \\
\hline & \multicolumn{2}{|c|}{ Marginal Effect } & \multicolumn{2}{|c|}{ Marginal Effect } \\
\hline & Estimate & z-Value & Estimate & z-Value \\
\hline Age & -0.0048 & -1.30 & -0.0008 & -0.30 \\
\hline Gender & -0.1002 & -1.56 & 0.0018 & 0.03 \\
\hline Marital Status & 0.059 & 0.99 & -0.0055 & -0.09 \\
\hline Education & 0.017 & 0.31 & 0.0115 & 0.21 \\
\hline Source of income & $-0.094^{*}$ & -1.71 & 0.134 & 1.14 \\
\hline Living Arrangement & $0.210^{* *}$ & 2.68 & $0.344^{* *}$ & 1.55 \\
\hline Sociability & 0.055 & 1.10 & -0.043 & -0.73 \\
\hline Number of siblings & -0.011 & -1.11 & 0.012 & 1.16 \\
\hline Number of sons & 0.028 & 1.33 & -0.01 & -0.49 \\
\hline Number of daughters & 0.0067 & 0.36 & 0.027 & 1.43 \\
\hline Children Age (Average) & 0.0052 & 1.62 & -0.003 & -1.00 \\
\hline Married Children (average) & 0.0806 & 0.88 & 0.144 & 1.34 \\
\hline Children's employment (average) & -0.0134 & -0.23 & 0.108 & 1.48 \\
\hline Livings (Average) & $0.136^{* *}$ & 2.48 & 0.079 & 1.36 \\
\hline Probit Regression & \multicolumn{2}{|c|}{$\begin{array}{c}\text { Number of obs. }=260 \\
\text { LR chi2 }(14)=44.79 \\
\text { Prob. } \geq \text { chi } 2=0.0000 \\
\text { Pseudo } R^{2}=0.1780 \\
\text { Irritation }=4 \\
\text { Log likelihood }=-103.44\end{array}$} & \multicolumn{2}{|c|}{$\begin{array}{c}\text { Number of obs. }=106 \\
\text { LR chi2 }(14)=30.59 \\
\text { Prob. } \geq \text { chi2 } 2=0.0063 \\
\text { Pseudo } R^{2}=0.3877 \\
\text { Irritation }=5 \\
\text { Log likelihood }=-24.15\end{array}$} \\
\hline
\end{tabular}

Coefficient significant at least 10 percent level is shown in bold type; and level of significance: ${ }^{* * *} \mathrm{p}<0.01 ;{ }^{* *} \mathrm{p}<0.05$; ${ }^{*} \mathrm{p}<0.10$. 
Table 5. Estimation Result for Elderly Received FinancialCare from Relatives

\begin{tabular}{|c|c|c|c|c|}
\hline \multirow{3}{*}{$\begin{array}{l}\text { Dependent Variables } \\
\text { Independent Variables }\end{array}$} & \multicolumn{2}{|c|}{ Financial Care (Rural Area) } & \multicolumn{2}{|c|}{ Financial Care (Urban Area } \\
\hline & \multicolumn{2}{|c|}{ Marginal Effect } & \multicolumn{2}{|c|}{ Marginal Effect } \\
\hline & Estimate & z-Value & Estimate & z-Value \\
\hline Age & $-0.016^{* * *}$ & -3.29 & 0.010 & 1.05 \\
\hline Gender & -0.094 & -1.03 & 0.087 & 0.56 \\
\hline Marital Status & -0.124 & -1.53 & 0.059 & 0.39 \\
\hline Education & -0.108 & -1.54 & 0.076 & 0.51 \\
\hline Source of income & 0.137 & 1.37 & 0.211 & 1.57 \\
\hline Living Arrangement & -0.047 & -0.57 & 0.116 & 0.58 \\
\hline Sociability & 0.029 & 0.45 & -0.095 & -0.83 \\
\hline Number of siblings & -0.0023 & -0.18 & -0.011 & -0.44 \\
\hline Number of sons & -0.0169 & -0.63 & -0.078 & -1.39 \\
\hline Number of daughters & -0.029 & -1.21 & 0.043 & 1.02 \\
\hline Children age & $0.007 *$ & 1.61 & -0.016 & -1.56 \\
\hline Married Children & $-0.226 * *$ & -2.65 & 0.083 & 0.61 \\
\hline Children's employment & $-0.413^{* * *}$ & -5.51 & $-0.193 *$ & -1.65 \\
\hline Livings & -.002 & -0.02 & 0.132 & 0.96 \\
\hline Probit Regression & \multicolumn{2}{|c|}{$\begin{array}{c}\text { Number of obs. }=260 \\
\text { LR chi2 }(14)=43.13 \\
\text { Prob. } \geq \text { chi } 2=0.0001 \\
\text { Pseudo } R^{2}=0.1256 \\
\text { Irritation }=3 \\
\text { Log likelihood }=-150.18\end{array}$} & \multicolumn{2}{|c|}{$\begin{array}{c}\text { Number of obs. }=106 \\
\text { LR chi2 }(14)=20.30 \\
\text { Prob. } \geq \text { chi2 }=0.1210 \\
\text { Pseudo } R^{2}=0.1390 \\
\text { Irritation }=4 \\
\text { Log likelihood }=-62.85\end{array}$} \\
\hline
\end{tabular}

Coefficient significant at least 10 percent level is shown in bold type; and level of significance: ${ }^{* * *} \mathrm{p}<0.01 ;{ }^{* *} \mathrm{p}<0.05$; ${ }^{*} \mathrm{p}<0.10$.

Table 6. Estimation Result for Elderly Received Personal Care from Relatives

\begin{tabular}{|c|c|c|c|c|}
\hline \multirow{3}{*}{$\begin{array}{l}\text { Dependent Variables } \\
\text { Independent Variables }\end{array}$} & \multicolumn{2}{|c|}{ Personal Care (Rural Area) } & \multicolumn{2}{|c|}{ Personal Care (Urban Area) } \\
\hline & \multicolumn{2}{|c|}{ Marginal Effect } & \multicolumn{2}{|c|}{ Marginal Effect } \\
\hline & Estimate & z-Value & Estimate & z-Value \\
\hline Age & $0.007 * *$ & 2.93 & $0.0008^{*}$ & 0.46 \\
\hline Gender & 0.019 & 0.48 & 0.003 & 0.42 \\
\hline Marital Status & 0.019 & 0.51 & .006 & 0.50 \\
\hline Education & 0.042 & 1.39 & -0.002 & -0.42 \\
\hline Sociability & -0.058 & -1.85 & 0.014 & 0.57 \\
\hline Number of siblings & -0.002 & -0.35 & -0.006 & -0.41 \\
\hline Number of sons & 0.006 & 0.50 & $-0.003 *$ & -0.45 \\
\hline Number of daughters & -0.005 & -0.45 & -0.089 & -0.41 \\
\hline Children Age & -0.0005 & -0.32 & 0.001 & 0.33 \\
\hline Married Children (average) & -0.007 & -0.13 & 0.015 & 0.74 \\
\hline Employment Children (average) & 0.004 & 0.01 & -0.008 & -0.49 \\
\hline Livings (Average) & $-0.083 * *$ & -2.73 & $.028 *$ & 0.69 \\
\hline Probit Regression & \multicolumn{2}{|c|}{$\begin{array}{c}\text { Number of obs. }=260 \\
\text { LR chi2 }(12)=39.05 \\
\text { Prob. } \geq \text { chi } 2=0.001 \\
\text { Pseudo } R^{2}=0.23 \\
\text { Irritation }=4 \\
\text { Log likelihood }=-64.99\end{array}$} & \multicolumn{2}{|c|}{$\begin{array}{c}\text { Number of obs. }=106 \\
\text { LR chi2 }(12)=23.71 \\
\text { Prob. } \geq \text { chi } 2=0.0222 \\
\text { Pseudo } R^{2}=0.46 \\
\text { Irritation }=6 \\
\text { Log likelihood }=-13.92\end{array}$} \\
\hline
\end{tabular}

Coefficient significant at least 10 percent level is shown in bold type; and Level of significance: ${ }^{* * *} \mathrm{p}<0.01 ;{ }^{* *} \mathrm{p}<0.05 ;{ }^{*} \mathrm{p}<0.10$. 
The marital status, education, source of income, number of son and married children are significant predictors in receiving practical care from relatives for rural respondents (Table7). Education, source of income, number of sons and marital status of children are significant factors (more likely) to receive practical care from relatives. This result indicates that spouse specifically wife is the most important personal and practical care provider in rural areas. On the other hand, marginal effect of education, source of income, number of sons and marital status of children were 18.5, 50.3, 7.8 and 28.9 percent, respectively. Thus marital status of the respondents is significant predictor. The marital status, source of income, living arrangement, marital status of children and employment status of children are significant predictors for the urban respondents to receive this care
(Table 7).

The marital status, number of siblings, number of sons and employment status of children are significant predictors to receive financial care for the rural elderly provided by friends and relative as presented in Table 8. More specifically, for each additional year of age, elderly are less likely to get financial care from friends and neighbors. This might happen as people get older; their social network shrinks, unable to maintain or their friends die. For each additional number of sons and sibling, elderly are less likely to get financial care from friends and neighbors. However, with increasing number of sons and siblings, the probability of receiving care increases from sons and siblings. However, for the urban respondents, there is no significant predictor in receiving financial care from friends and neighbors.

Table 7. Estimation Result for Elderly Received Practical Care from Relatives

\begin{tabular}{|c|c|c|c|c|}
\hline \multirow{3}{*}{$\begin{array}{l}\text { Dependent Variables } \\
\text { Independent Variables }\end{array}$} & \multicolumn{2}{|c|}{ Practical Care (Rural Area) } & \multicolumn{2}{|c|}{ Practical Care (Urban Area } \\
\hline & \multicolumn{2}{|c|}{ Marginal Effect } & \multicolumn{2}{|c|}{ Marginal Effect } \\
\hline & Estimate & z-Value & Estimate & z-Value \\
\hline Age & -0.0007 & -0.16 & -0.011 & -1.50 \\
\hline Gender & -0.166 & -2.14 & -0.231 & -1.63 \\
\hline Marital Status & $-0.069 * *$ & -0.93 & $-0.253^{*}$ & -2.00 \\
\hline Education & $0.185^{* *}$ & 2.57 & 0.108 & 0.80 \\
\hline Source of income & $0.503^{* * *}$ & 5.26 & $0.429 * *$ & 3.13 \\
\hline Living Arrangement & -0.031 & -0.39 & $-0.012^{*}$ & 2.35 \\
\hline Sociability & -0.026 & -0.42 & -0.055 & -0.47 \\
\hline Number of siblings & -0.011 & -0.88 & 0.021 & 0.91 \\
\hline Number of sons & $0.078 * *$ & 3.03 & 0.013 & 0.26 \\
\hline Number of daughters & -0.004 & -0.20 & -0.045 & -1.07 \\
\hline Children Age & 0.016 & 0.44 & -0.001 & -0.14 \\
\hline Married Children (average) & $0.289 * *$ & 2.69 & $0.333 * *$ & 2.35 \\
\hline Employed Children (average) & 0.075 & 1.10 & $0.225^{*}$ & 1.86 \\
\hline Livings (Average) & 0.022 & 0.30 & 0.065 & 0.46 \\
\hline Probit Regression & \multicolumn{2}{|c|}{$\begin{array}{c}\text { Number of bs. }=260 \\
\text { LR chi2 }(14)=92.63 \\
\text { Prob. } \geq \text { chi2 }=0.0000 \\
\text { Pseudo } \mathrm{R}^{2}=0.3019 \\
\text { Irritation }=4 \\
\text { Log likelihood }=-107.088\end{array}$} & \multicolumn{2}{|c|}{$\begin{array}{c}\text { Number of bs. }=106 \\
\text { LR chi2 }(16)=28.83 \\
\text { Prob. } \geq \text { chi2 }=0.0110 \\
\text { Pseudo } \mathrm{R}^{2}=0.2052 \\
\text { Irritation }=4 \\
\text { Log } \\
\text { likelihood=-55.838 }\end{array}$} \\
\hline
\end{tabular}

Coefficient significant at least 10 percent level is shown in bold type; and Level of significance: ${ }^{* * *} \mathrm{p}<0.01 ;{ }^{* *} \mathrm{p}<0.05 ;{ }^{*} \mathrm{p}<0.10$. 
Table 8. Estimation Results for Receiving Financial care from Friends and Neighbors

\begin{tabular}{|c|c|c|c|c|}
\hline \multirow{3}{*}{$\begin{array}{l}\text { Dependent Variables } \\
\text { Independent Variables }\end{array}$} & \multicolumn{2}{|c|}{ Financial Care (Rural Area) } & \multicolumn{2}{|c|}{ Financial Care (Urban Area } \\
\hline & \multicolumn{2}{|c|}{ Marginal Effect } & \multicolumn{2}{|c|}{ Marginal Effect } \\
\hline & Estimate & z-Value & Estimate & z-Value \\
\hline Age & $-0.094 * *$ & -2.24 & -0.00009 & -0.03 \\
\hline Gender & -0.04 & -0.50 & -0.013 & -0.21 \\
\hline Marital Status & $-0.17 * *$ & -2.39 & -0.031 & -0.44 \\
\hline Education & 0.0176 & 0.29 & -0.083 & -2.29 \\
\hline Source of income & -0.03 & -0.38 & 0.053 & 1.34 \\
\hline Living Arrangement & 0.074 & 1.13 & -0.198 & -1.07 \\
\hline Sociability & -0.0135 & -0.24 & -0.036 & -0.88 \\
\hline Number of siblings & $-0.029 * *$ & -2.47 & -0.0137 & -1.34 \\
\hline Number of sons & $-0.038 *$ & -1.70 & 0.0256 & 1.09 \\
\hline Number of daughters & -0.025 & -1.25 & -0.0027 & -0.16 \\
\hline Children Age (Average) & 0.0012 & 0.35 & -0.0043 & -1.41 \\
\hline Married Children (average) & -0.094 & -1.03 & 0.0004 & 0.01 \\
\hline Empled Children (average) & $-0.203^{* *}$ & -3.83 & -0.047 & -0.74 \\
\hline Livings (Average) & 0.0215 & 0.32 & -0.001 & -0.02 \\
\hline Probit Regression & \multicolumn{2}{|c|}{$\begin{array}{c}\text { Number of obs. }=260 \\
\text { LR chi2 }(14)=40.63 \\
\text { Prob. } \geq \text { chi } 2=0.0002 \\
\text { Pseudo } R^{2}=0.1369 \\
\text { Irritation }=4 \\
\text { Log likelihood }=-128.05\end{array}$} & \multicolumn{2}{|c|}{$\begin{array}{c}\text { Number of bs. }=106 \\
\text { LR chi2 }(14)=13.56 \\
\text { Prob. } \geq \text { chi2 }=0.4827 \\
\text { Pseudo } R^{2}=0.204 \\
\text { Irritation }=5 \\
\text { Log likelihood }=-26.34\end{array}$} \\
\hline
\end{tabular}

Coefficient significant at least 10 percent level is shown in bold type; and Level of significance: ${ }^{* * *} \mathrm{p}<0.01 ;{ }^{* *} \mathrm{p}<0.05$; ${ }^{*} \mathrm{p}<0.10$.

Table 9. Estimation Results for the Elderly Received Practical care from Friends and Neighbors

\begin{tabular}{|c|c|c|c|c|}
\hline \multirow{3}{*}{$\begin{array}{c}\text { Dependent variable } \\
\text { Independent Variables }\end{array}$} & \multicolumn{2}{|c|}{ Practical Care (Rural Area) } & \multicolumn{2}{|c|}{ Practical Care (Urban Area) } \\
\hline & \multicolumn{2}{|c|}{ Marginal Effect } & \multicolumn{2}{|c|}{ Marginal Effect } \\
\hline & Estimate & z-Value & Estimate & z-Value \\
\hline Age & -0.0008 & -0.17 & -0.002 & -0.28 \\
\hline Gender & 0.020 & 0.21 & -0.171 & -1.31 \\
\hline Marital Status & -0.071 & -0.86 & $0.276^{*}$ & 2.86 \\
\hline Education & $-0.134 *$ & -1.83 & 0.142 & 0.96 \\
\hline Source of income & $0.266^{* *}$ & 3.25 & $0.196 * *$ & 2.14 \\
\hline Living Arrangement & -0.097 & -1.14 & $-0.288 *$ & -1.35 \\
\hline Sociability & -0.067 & -1.01 & 0.092 & 0.89 \\
\hline Number of siblings & 0.0127 & 0.96 & -0.007 & -0.34 \\
\hline Number of sons & 0.021 & 0.77 & 0.009 & 0.20 \\
\hline Number of daughters & -0.019 & -0.77 & -0.053 & -1.47 \\
\hline Children Age (Average) & -0.003 & -0.71 & 0.006 & 0.80 \\
\hline Married Children (average) & 0.085 & 0.85 & $-0.004 *$ & -0.03 \\
\hline Employed Children (average) & -0.0167 & -0.22 & $0.006 *$ & 0.06 \\
\hline Livings (Average) & -0.096 & -1.21 & -0.034 & -0.29 \\
\hline Probit Regression & \multicolumn{2}{|c|}{$\begin{array}{c}\text { Number of bs. }=260 \\
\text { LR chi2 (14) }=25.34 \\
\text { Prob. } \geq \text { chi2 }=0.0314 \\
\text { Pseudo } R^{2}=0.0707 \\
\text { Irritation }=3 \\
\text { Log likelihood }=-166.44\end{array}$} & \multicolumn{2}{|c|}{$\begin{array}{c}\text { Number of bs. }=106 \\
\text { LR chi2 (14) }=18.72 \\
\text { Prob. } \geq \text { chi2 }=0.1761 \\
\text { Pseudo } R^{2}=0.1482 \\
\text { Irritation }=4 \\
\text { Log likelihood }=-53.79\end{array}$} \\
\hline
\end{tabular}

Coefficient significant at least 10 percent level is shown in bold type; and Level of significance: ${ }^{* * *} \mathrm{p}<0.01 ;{ }^{* *} \mathrm{p}<0.05 ;{ }^{*} \mathrm{p}<0.10$. 
In the rural area, education and source of income are significant predictors in receiving practical care by the respondents (Table 9). It means that if the respondents are educated, the elderly are less likely to receive this care from friends and neighbors. Actually, poor elderly who are unable to fulfill their daily needs and children do not look after properly or unable to look after are received financial care from friend and neighbor. Educated elderly are financially more secure than uneducated. On the other hand, if the respondents have own source of income, the probability of receiving this care from friends and neighbors rises by $26.6 \%$. For the urban respondents, marital status, living arrangement, source of income, marital status of children and employed children are significant predictors.

\subsection{Vulnerability to Receive Care in Urban and Rural Areas}

Table3, 4, 5, 6, 7, 8, and 9 represent the estimated the marginal effect of independent variables on dependent variable which indicate the probability of receiving home care when dichotomous and continuous independent variables changes. Table10 shows the estimated probability value to receive particular care considering independents variable explained in the methodology separately for urban and rural area. Table10 shows that probability of receiving financial and personal care from spouse and children are approximately same in both urban and rural area. In rural area, the probability of receiving financial and practical care is 90 and 4 percent, respectively. Conversely, in urban area, it is 93 and 5 percent, respectively. In rural area probability of receiving practical care is $84 \%$, but in urban area, it is $95 \%$ from spouse and children. The probability of receiving all in three types of care by the elderly from spouse and children is more in urban area. On the down side, probability of receiving all in three types of care by elderly from relatives is more in rural area. Probability of receiving financial and practical care in rural area is 64 and 77 percent respectively but in urban area $45 \%$ and $64 \%$ respectively. Table8 also indicates that elderly are more vulnerable in receiving personal care than financial and practical care. Probability of receiving financial and practical care is more in rural area than in urban area form friend and neighbors as rural area.

Table 10. Estimated Probability Value to receive a Care in urban and rural areas

\begin{tabular}{|c|c|c|}
\hline Care's Name & $\begin{array}{c}\text { Estimated probability to receive } \\
\text { care by elderly in Rural area }\end{array}$ & $\begin{array}{c}\text { Estimated probability to } \\
\text { receive care by elderly in } \\
\text { Urban area }\end{array}$ \\
\hline Financial care received from spouse and children & 0.90 & 0.93 \\
\hline Personal care received from spouse or children & 0.04 & 0.06 \\
\hline Practical care received from spouse or children & 0.85 & 0.95 \\
\hline Financial care received from relatives & 0.64 & 0.45 \\
\hline Personal care received from relatives & 0.01 & 0.001 \\
\hline Practical care received from relatives & 0.77 & 0.64 \\
\hline Financial care received from friends and neighbors & 0.22 & 0.05 \\
\hline Practical care received from friends and neighbors & 0.45 & 0.24 \\
\hline
\end{tabular}

Table 11. Home care requirement and Expected Provider

\begin{tabular}{|c|c|c|c|c|c|c|}
\hline \multirow{2}{*}{ Types of care } & \multicolumn{2}{|c|}{ Financial Care } & \multicolumn{2}{c|}{ Personal Care } & \multicolumn{2}{c|}{ Practical Care } \\
\hline \multirow{2}{*}{$\begin{array}{c}\text { Care requirements by } \\
\text { areas }\end{array}$} & Urban & Rural & Urban & Rural & Urban & Rural \\
\cline { 2 - 8 } & $83.7 \%(87)$ & $95 \%(245)$ & $32.07 \%(34)$ & $28.95 \%(77)$ & $85.84 \%(91)$ & $81.95 \%(218)$ \\
\hline \multicolumn{7}{|c|}{ Expected care by areas from: } \\
\hline Spouse & $9.9 \%(10)$ & $9.1 \%(23)$ & $24 \%(26)$ & $25.19 \%(67)$ & $15.09 \%(16)$ & $15 \%(39)$ \\
\hline Children & $90.57 \%(96)$ & $90.60 \%(241)$ & $91.51 \%(97)$ & $95 \%(247)$ & $95.28 \%(95)$ & $93.84 \%(244)$ \\
\hline Relatives & $27.52 \%(29)$ & $24.06 \%(64)$ & $49.28 \%(52)$ & $49.61 \%(129)$ & $53.77 \%(57)$ & $44.23 \%(115)$ \\
\hline Friends \& Neighbors & $1.8 \%(2)$ & $0.75 \%(2)$ & $2.8 \%(3)$ & $1.15 \%(3)$ & $4.71 \%(5)$ & $1.15 \%(3)$ \\
\hline Government & $74.52 \%(79)$ & $91.92 \%(239)$ & $11.32 \%(12)$ & $5 \%(13)$ & $3.77 \%(4)$ & $1.15 \%(3)$ \\
\hline NGO & $58.49 \%(62)$ & $88.07 \%(229)$ & $13.21 \%(14)$ & $6.9 \%(18)$ & $16.04 \%(17)$ & $2.69 \%(7)$ \\
\hline
\end{tabular}

Source: survey data 


\subsection{Current and Future Home Care Requirement}

Table 11 represents the current home care requirement and expected provider for the respondents in rural and urban areas. Around 83 and 95 percent of the respondents require financial care in the urban and rural area, respectively. This indicates that elderly in rural area are economically more vulnerable than urban area. Beside, personal and practical care requirement are more for elderly in urban area than rural area. The elderly are very much consistent to receive all kind of care from their children like financial, personal and practical in the both areas. Subsequently, they expect care from government and NGOs. Beside, in both areas, nearly 50 percent of elderly expect their future personal and practical care from relatives, for the financial care it is almost 25 percent.

\section{Conclusion and Policy Recommendations}

The findings revealed that the elderly in both urban and rural areas are more vulnerable in receiving personal care. Besides, the elderly in rural area are less vulnerable in receiving care from relatives, friends and neighbors than urban area. With the increasing age, elderly in both areas are becoming vulnerable to receive all kind of care. The previous employment status, number of children and current employment status of children play important roles is receiving cares. Most of the cases, they were employed in informal sector, so they have no permanent income sources. Another common trend is found to take few children. Consequently, the elderly become more vulnerable to receive care. As the financial assistance has positive impact on the wellbeing of the status of the elderly, work opportunity or income generating activity can be arranged if they are able to work. It might be helpful for the elderly to reduce their loneliness and isolation of the social network. In addition, the coverage and amount of old age allowance can be extended when the elderly are found incapable to work and required. Pensioned scheme can be introduced among the informal workers so that they can be benefited in their elderly stage. Elderly prefer to live in family atmosphere. So the children can encourage taking all responsibilities for the elderly. In this case, "The Parent's Care Act, 2013" needs to be implemented properly. Family is the primary support provider of elderly in Bangladesh. Thus efforts should be taken to promote the values of family togetherness. Home based care can be more effective for the elderly than institutional care; thus local government can set 'Elderly Care Centre' that will serve the elderly according their need like practical and personal care with pay or without pay.

\section{Acknowledgements}

First author is very grateful to the SUST research center for grant to conduct this research.

\section{REFERENCES}

[1] Hossain, M. R. (2005), “Aging in Bangladesh and its Population Projections”, Pakistan Journal of Social Sciences, Vol. 3 No.1, pp. 62-67.

[2] Khanam, M. A., Streatfield, P. K., Kabir, Z. N., Qiu, C., Cornelius, C. and Wahlin, Å. (2011), "Prevalence and patterns of multimorbidity among elderly people in rural Bangladesh: a cross-sectional study”, Journal of health, population, and nutrition, Vol. 29 No. 4, pp. 406.

[3] Uddin, M. T., Islam, M. N. and Kabir, A. (2012), "Demographic Dependency of Aging Process in Bangladesh", Pakistan Academy of Science, Nol. 49 No. 3, pp. 209-218.

[4] IDB. (2015). International Data Base. Retrieved 28/4/2015, from US Census Boreau http://www.census.gov/population/in ternational/data/idb/informationGateway.php

[5] Dhillon, P. Laishram, L. Gopal, A. (2016) "Ageing and changing patterns in familial structure for older persons in India: a decomposition analysis", Quality in Ageing and Older Adults, Vol. 17 No. 2, pp.83 - 96

[6] Hossain, F. (2013), "Needs of the Destitute Elderly of Bangladesh: A Sociological Inquiry”, Middle East Journal of Age \& Ageing, Vol. 10 No. 5, pp. 21-30.

[7] Hossain, M. I., Akhtar, T. and Uddin, M. T. (2006), "The elderly care services and their current situation in Bangladesh: An understanding from theoretical perspective”, Journal of Medical Sciences, Vol. 6 No.2, pp. 131-138.

[8] Tostensen, A. (2004). Towards feasible social security systems in sub-Saharan Africa: Chr. Michelsen Institute.

[9] Gillion, C. (2000), Social security pensions: Development and reform: International Labour Organization

[10] Bongaarts, J. and Zimmer, Z. (2002), "Living arrangements of older adults in the developing world an analysis of demographic and health survey household surveys”, The Journals of Gerontology Series B: Psychological Sciences and Social Sciences, Vol. 57 No.3, pp. 145-157.

[11] Asadullah, M., Kuvalekar, K., Katarki, B., Malamardi, S., and Khadka, S. (2012), “A study of Morbidity Profile and Quality of Life of Inmates in Old Age Homes in Udupi District, Karnataka, India”, International Journal of Basic and Applied Medical Sciences, Vol. 2 No. 3, pp. 91-97.

[12] Rahman, H. Z., Choudhury, L. A. and Ali, K. S. (2011). Social Safety Nets in Bangladesh. Review of Issues and Analytical Inventory. Dhaka: Power and Participation Research Centre.

[13] Dubey, A., Bhasin, S., Gupta, N. and Sharma, N. (2011), “A study of elderly living in old age home and within family set-up in Jammu”, Stud Home Com Sci., Vol. 5 No.2, pp. 93-98.

[14] Kabir, M. and Salam, M. A. (2001), The effects of various interventions on the welfare of the elderly: Evidence from micro-study, Dhaka: Centre for Policy Dialogue (CPD). 
[15] Kalam, I. and Khan, H. T. (2006), "Morbidities among older people in Bangladesh: evidence from an ageing survey", BRAC University Journal, Vol. 3 No.2, pp. 75-83.

[16] Munsur, A. M., Tareque, I. and Rahman, K. (2013), "Determinants of living arrangements, health status and abuse among elderly women: A study of rural Naogaon district, Bangladesh”, Journal of International Women's Studies, Vol. 11 No. 4, pp. 162-176.

[17] Khan, M. N., Mondal, M. N. I., Hoque, N., Islam, M. S. and Shahiduzzaman, M. (2014), "A study on quality of life of elderly population in Bangladesh”, American Journal of Health Research, Vol. 2 No. 4, pp. 152-157.

[18] Brieland, Donald, Costin, Lela B. and Atherton (1985), Contemporary Social Work: An Introduction to Social Work and Welfare, McGraw-Hill, U.S.A.

[19] Raikhola, P. S. and Kuroki, Y. (2009), “Aging and Elderly Care Practice in Japan: Main Issues, Policy and Program Perspective; What Lessons Can Be Learned from Japanese Experiences?”, Dhaulagiri Journal of Sociology and Anthropology, Vol. 3, pp. 41-82.

[20] Kalwij, A., Pasini, G. and Wu, M. (2014), "Home care for the elderly: the role of relatives, friends and neighbors”, Review of Economics of the Household, Vol. 12 No 2, pp. 379-404.
[21] AIHW, (2016), Australian Institute of Health and Welfare. Retrieved from aihw.gov.au/ informal -care -ageing.

[22] Ahmed, S. M. (2012), The elderly in Bangladesh: does anybody care for them? Retrieved from http://syedmasudahm ed.blogspot.com/2012/04/elderly-in-bangladesh-does-anybod y-care.html.

[23] Kim, B. J. and Sung, K (2011), “Teaching repayment of parents kindness”, Educational Gerontology, Vol. 37, pp. 899-909.

[24] Razzaque, M. A., \& Islam, M. S. (1997), “Ageing in Bangladesh and public policy”, Journal of Family Welfare, Vol. 43 No.1, pp. 51-5.

[25] Khan, N. A. (2006), “Acanthamoeba: biology and increasing importance in human health”, FEMS microbiology reviews, Vol. 30 No. 4, pp. 564-595

[26] Valadez, J. and Bamberger, M. (1994). Monitoring and evaluating social programs in developing countries, World Bank, Washington, D.C.

[27] Schipper, L, Katrien G. Luijkx, Bert R. Meijboom,René Schalk,Jos M.G.A. Schols, (2015) "Access to long-term care: perceptions and experiences of older Dutch people", Quality in Ageing and Older Adults, Vol. 16 No. 2, pp.83-93. 